\title{
Does External Debt Matter for Investment: Evidence from GMM
}

\author{
Prof. Dr. Halit Yanıkkaya (Gebze Technical University, Turkey) \\ Assoc. Prof. Dr. Taner Turan (Gebze Technical University, Turkey)
}

\begin{abstract}
In theory, the main channel which through external debt would affect the growth rate is investment. On the one hand, external debt would boost the investment by providing more resources than domestically available. On the other hand, external debt would create a disincentive effect, as suggested by debt overhang arguments. Since it is not clear which effect will dominate in practice, empirical studies would be helpful to shed light on the issue. Moreover, one can argue that the effect of external debt on the private and public investment does not need to be the same. Therefore, aside from total investment we investigate the impact of external debt on disaggregated investment. We use dynamic panel analysis and data for a large sample of countries to investigate the subject at hand. Our results indicate that there exists a negative relationship between external debt and total investment. Furthermore, we find that both total and public external debt lowers the private investment, consistent with debt overhang arguments. On the other hand, there is no relationship between the external debt and government investment.
\end{abstract}

\section{Introduction}

Many developing countries borrowed in international markets in 1970s with relatively low interest rates. However, circumstances started to change in early 1980s and these countries experienced severe difficulties in meeting their debt obligations. The external debt and its effects then become more relevant and focal point in academic and policy circles. Despite extensive efforts, whether the external debt is beneficial or harmful to investment has been an unresolved issue for a long time. On the one hand, the external debt means additional source of funding to spend on investment and enhance the productive capacity. On the other hand, external debt would create certain uncertainties and distort economic decisions.

We investigate the impact of external debt on investment for more than sixty developing countries by means of the system GMM estimations. Our empirical findings indicate that external debt exerts a significant negative impact on investment in general. Moreover, both total and public external debt negatively affect private investment.

The paper is organized as follows: We briefly review the literature in section 2, explain model specification and data in section 3, report and discuss empirical findings in section 4, and finally conclude in section 5.

\section{Literature Review}

Many developing countries lack of the adequate capital stock to support investment rates. External borrowing enables these countries to make more investment than domestic savings could afford. If these external sources of financing are used for productive investment, developing countries can have higher growth rates. On the other hand, external debt could have a negative effect via different channels, such as debt overhang arguments of Krugman (1988) and Sachs (1989) and disincentives for investment, as discussed in many studies among them Fosu (1996, 1999), Clements et. al. (2003). In the presence of debt overhang, an increase in output largely accrues to foreign lenders. Therefore, a high external debt and/or debt servicing could distort the investment decisions by acting like a tax on investment or output. Moreover, a high level of external debt inevitably creates an uncertainty, for example as to how debt repayments will be financed or who will bear the burden. Furthermore, the interaction between external debt and uncertainty can change the quality of investment as well (Fosu, 1996; Sen et al., 2007; Clements et. al., 2003). Investment projects that have quick returns are more likely to be realized even though they are not the most efficient or needed ones while the better projects with long term returns are postponed or even cancelled. Another important effect of external debt on the economy is to change the composition of public spending (Mahdavi, 2004; Desphande, 1997). This means that, due to the debt payments, governments lower the share of public spending on investment. Furthermore, if public and private investments are complements rather than substitutes, then a decline in public investment will cause a further reduction in private investment. Finally, external debt also affects growth by crowding out as debt servicing means less funds or savings available for new investment including private one.

Additionally, external debt would make a country more vulnerable and fragile to external conditions and debt crises (see, Reinhart et al., 2003). Furthermore, if developing countries have difficulties in borrowing abroad in their own currencies, called "original sin" in the literature such as Eichengreen et al. (2007), a deprecation in real exchange rate will make debt servicing more difficult and induce a vicious cycle, causing low growth rates and investment. Some studies, such as Fosu (1996), Pattilo et al. (2004), Clements et al. (2003), Schcalarek (2004), Cordella et al. (2005) and Daud and Podivinsky (2012) empirically examine the relationship between external debt and investment. 


\section{Model and Data}

An empirical growth model commonly used in the literature is employed to examine the effects of external debt on both economic growth and investment. In general form, this model is specified as:

$$
\gamma_{i t}=F\left(y_{t}, k_{t}, h_{t} ; Z_{(t)}\right)
$$

where $\gamma$ it is country i's the level of gross fixed capital formation in period $t$, yt is initial GDP per capita, kt is the gross fixed capital formation as percentage of GDP, and ht is secondary school enrollment ratios. A large number of economic and political factors are employed as control variables in the vector Zt. These factors include fertility rates, trade shares (\% of GDP), government consumption (\% of GDP), inflation rates, domestic credit provided by financial sector ( $\%$ of GDP), interest rates, and a measure of regime durability. Total external debt stocks, longterm private sector external debt stocks, and long-term public sector external debt stocks (all in \% of GDP) are employed.

The dependent variable is the five-year averages of total investment (government and private investment as well) levels. Lagged investment rates, initial GDP per capita levels, and lagged growth rates are also used in the estimates. Other control variables included in the investment estimates are trade shares, government consumption, inflation rates, domestic credit provided by financial sector, interest rates, and a measure of durability. Time dummies for nine periods are used in the both sets of estimates (not reported).

Data for growth rates, fertility rates, government consumption, inflation, interest rates, domestic credit provided by financial sector, and trade shares are from the World Bank's World Development Indicators (2017). The main data source for debt and investment figures are the World Bank, International Debt Statistics and IMF Investment and Capital Stock database, respectively. Data for secondary school enrolment ratios are from Barro-Lee educational attainment dataset (see, Lee and Lee, 2016). Data for initial GDP per capita are from Penn World Table 8.0 (Feenstra et al., 2015). Data for the regime durability are from the Polity IV data set (Marshall and Jaggers, 2005).

The model is estimated for a panel of over sixty developing countries for nine five-year periods: 1970-74 to 2010-2014. The sample size for each estimated equation is determined by the data availability. Our model is estimated by using the system GMM (Generalized Method of Moments) methods. GMM estimators are regarded as well-suited to deal with some econometric problems frequently encountered in the growth literature, such as endogeneity, heteroscedasticity and overidentification. Baum et al. (2003) claim that heteroscedasticity is an omnipresent problem in empirical works and using GMM is a more efficient way of handling heteroscedasticity problem than instrumental variable (IV) estimator. The number of groups (countries in our case) should be more than or equal to the number of instruments, and we test the validity of instruments with the Hansen test. High $p$ values for these tests in our estimations indicate that our group of instruments is exogenous and our instruments are strong enough. At the same time, Arellano-Bond test is applied both for fixed effects and residuals in differences to test for autocorrelation. AR (1) and AR (2) tests are Arellano-Bond tests for autocorrelation in our estimations. In all our estimations, AR (1) tests are significant (not reported), and AR (2) tests are insignificant. This means there is autocorrelation in AR (1); however, we observe no autocorrelation in first difference levels of AR (2).

\section{Empirical Results and Discussion}

Table 1 reports the GMM estimates for the investment levels. Investment rates seem to be very persistent given the significantly positive estimated coefficients on lagged investment levels. Inflation rate has a negative effect while the financial development has a positive effect on investment in general. These results are in line with theoretical expectations. We present a strong evidence for the argument that inflation rate distorts investment decisions and harmful for economic activity. Similarly, we find that financial development promotes investment by possibly increasing available funds and ensuring a better allocation among alternative uses. Other control variables don't have any significant impact. 
Dep. Var.: Gross investment (log, \% of GDP)

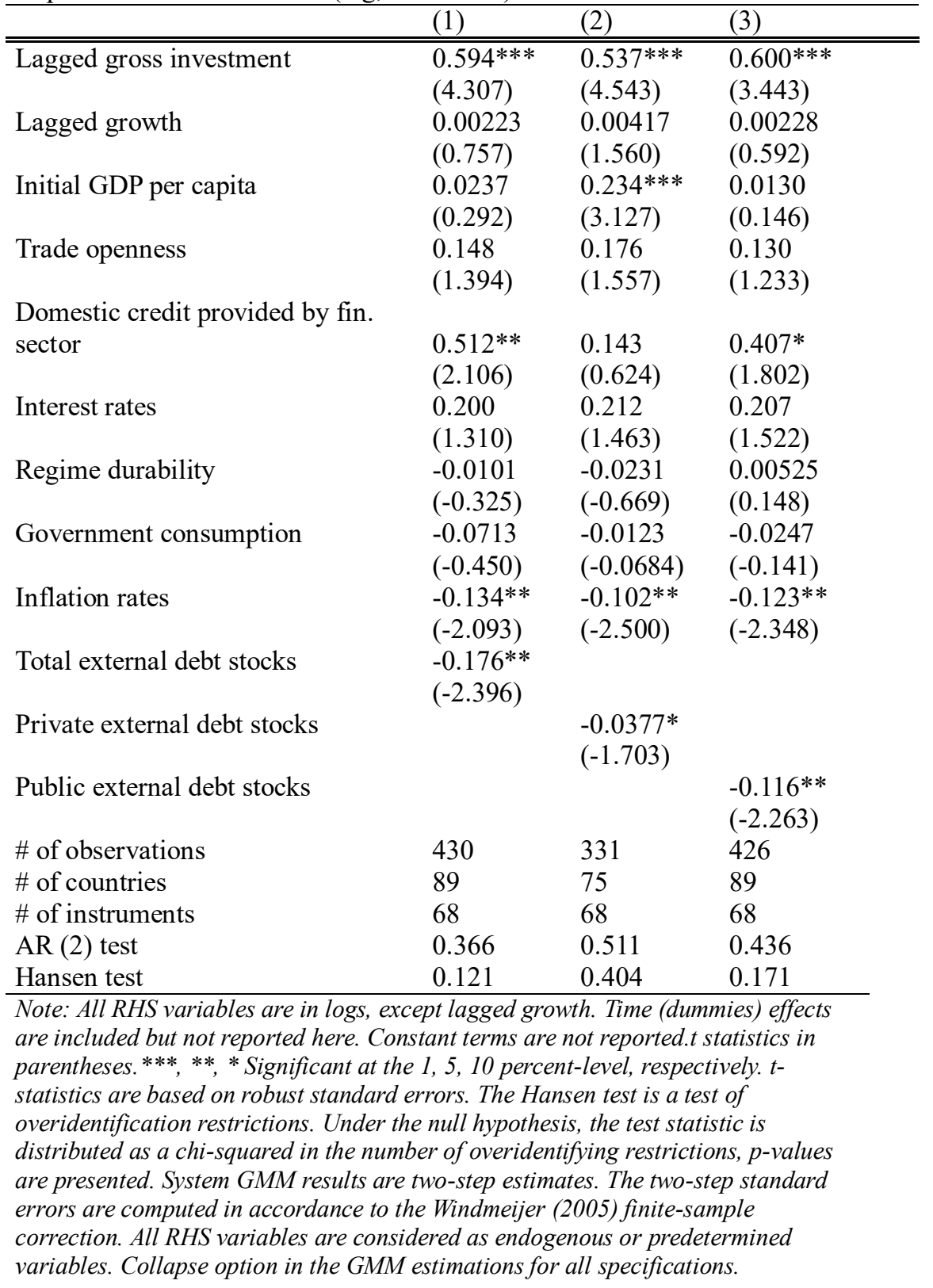

Table 1. External Debt and Investment

The statistically significant and negative coefficient in Table 1 imply that external debt stocks lower investment, which thus substantially supports the predictions of debt overhang hypothesis. Our results are similar with some previous studies like Cordella et al. (2005) but different from that of Daud and Podivinsky (2012), that fails to find a negative relationship between external debt and investment. We then also investigate the growth effect of public and private external debt, separately in the last two columns of Table 1 . The significantly negative coefficients show that both public and private external debt stocks reduce investment.

We then consider the investment effects of government and private components of total investment levels. First three columns of Table 2 report that none of the measures of external debt is significant implying that external debt do not affect government investment levels. The statistically significant and negative estimated coefficients on total external and public debt stocks show that both total debt stock and public debt reduce private investment. These results clearly imply that the dynamics of government and private investment are rather different from each other. Regarding the insignificance of external debt stock on government investment, our result is in line with that of Clements et al. (2003). However, the negative association between total and public external debt and private investment is totally consistent with the debt overhang hypothesis. One may argue that the debt overhang hypothesis is more relevant for public external debt rather than private debt. In other words, it is sensible to assert that what matters more for private investment decisions is public not private external debt stock. Therefore, our results lend a strong evidence for debt overhang hypothesis by looking at the effect of public and private external debt on both public and private investment. 
Dep. Var.: Government or private investment levels (log, \% of GDP)

\begin{tabular}{|c|c|c|c|c|c|c|}
\hline & (1) & (2) & (3) & (4) & (5) & (6) \\
\hline & \multicolumn{3}{|c|}{ Government investment levels (log) } & \multicolumn{3}{|c|}{ Private investment levels $(\log )$} \\
\hline Lagged govt. investment & $\begin{array}{l}0.724 * * * \\
(7.485)\end{array}$ & $\begin{array}{c}0.512 * * * \\
(5.105)\end{array}$ & $\begin{array}{c}0.698 * * * \\
(6.724)\end{array}$ & $\begin{array}{l}-0.0395 \\
(-0.407)\end{array}$ & $\begin{array}{l}-0.0940 \\
(-0.846)\end{array}$ & $\begin{array}{l}-0.0168 \\
(-0.197)\end{array}$ \\
\hline Lagged private investment & $\begin{array}{l}-0.0285 \\
(-0.240)\end{array}$ & $\begin{array}{l}0.0917 \\
(0.893)\end{array}$ & $\begin{array}{l}-0.0164 \\
(-0.130)\end{array}$ & $\begin{array}{c}0.695 * * * \\
(4.444)\end{array}$ & $\begin{array}{l}0.656 * * * \\
(6.391)\end{array}$ & $\begin{array}{l}0.740 * * * \\
(5.354)\end{array}$ \\
\hline Lagged growth & $\begin{array}{l}0.00515 \\
(1.077)\end{array}$ & $\begin{array}{l}0.0115 * * * \\
(3.172)\end{array}$ & $\begin{array}{l}0.00474 \\
(0.986)\end{array}$ & $\begin{array}{c}-0.000566 \\
(-0.122)\end{array}$ & $\begin{array}{l}0.00261 \\
(0.730)\end{array}$ & $\begin{array}{l}-0.000322 \\
(-0.0613)\end{array}$ \\
\hline Initial GDP per capita & $\begin{array}{l}-0.0361 \\
(-0.428)\end{array}$ & $\begin{array}{c}0.172 \\
(1.658)\end{array}$ & $\begin{array}{l}-0.0573 \\
(-0.608)\end{array}$ & $\begin{array}{l}-0.0120 \\
(-0.119)\end{array}$ & $\begin{array}{l}0.272 * * \\
(2.474)\end{array}$ & $\begin{array}{l}-0.0218 \\
(-0.209)\end{array}$ \\
\hline Trade openness & $\begin{array}{l}0.0191 \\
(0.125)\end{array}$ & $\begin{array}{l}0.0786 \\
(0.485)\end{array}$ & $\begin{array}{l}0.0262 \\
(0.149)\end{array}$ & $\begin{array}{l}0.257^{*} \\
(1.730)\end{array}$ & $\begin{array}{c}0.291 \\
(1.466)\end{array}$ & $\begin{array}{c}0.227 \\
(1.472)\end{array}$ \\
\hline $\begin{array}{l}\text { Domestic credit provided } \\
\text { by fin. sector }\end{array}$ & $\begin{array}{c}0.201 \\
(0.747)\end{array}$ & $\begin{array}{c}-0.226 \\
(-0.821)\end{array}$ & $\begin{array}{c}0.158 \\
(0.576)\end{array}$ & $\begin{array}{c}0.611 * * \\
(2.243)\end{array}$ & $\begin{array}{c}0.199 \\
(0.515)\end{array}$ & $\begin{array}{l}0.473 * \\
(1.746)\end{array}$ \\
\hline Interest rates & $\begin{array}{l}-0.0379 \\
(-0.185)\end{array}$ & $\begin{array}{c}0.325 \\
(0.999)\end{array}$ & $\begin{array}{l}-0.0198 \\
(-0.105)\end{array}$ & $\begin{array}{c}0.252 \\
(1.635)\end{array}$ & $\begin{array}{c}0.406^{* *} \\
(2.103)\end{array}$ & $\begin{array}{l}0.321 * * \\
(2.254)\end{array}$ \\
\hline Regime durability & $\begin{array}{l}0.0672 \\
(1.151)\end{array}$ & $\begin{array}{l}-0.0316 \\
(-0.540)\end{array}$ & $\begin{array}{l}0.0763 \\
(1.483)\end{array}$ & $\begin{array}{l}-0.0310 \\
(-0.750)\end{array}$ & $\begin{array}{l}-0.0811 \\
(-1.605)\end{array}$ & $\begin{array}{l}-0.0272 \\
(-0.648)\end{array}$ \\
\hline Government consumption & $\begin{array}{l}-0.0373 \\
(-0.175)\end{array}$ & $\begin{array}{l}0.0746 \\
(0.329)\end{array}$ & $\begin{array}{l}-0.0393 \\
(-0.205)\end{array}$ & $\begin{array}{l}0.0697 \\
(0.472)\end{array}$ & $\begin{array}{l}-0.0234 \\
(-0.137)\end{array}$ & $\begin{array}{l}0.0638 \\
(0.401)\end{array}$ \\
\hline Inflation rates & $\begin{array}{l}-0.0974 \\
(-1.520)\end{array}$ & $\begin{array}{l}-0.0964 \\
(-1.665)\end{array}$ & $\begin{array}{l}-0.0931 \\
(-1.401)\end{array}$ & $\begin{array}{c}-0.174 * * \\
(-2.234)\end{array}$ & $\begin{array}{l}-0.129^{*} \\
(-1.867)\end{array}$ & $\begin{array}{l}-0.170 * * \\
(-2.411)\end{array}$ \\
\hline Total external debt stocks & $\begin{array}{l}-0.0917 \\
(-1.514)\end{array}$ & & & $\begin{array}{l}-0.204 * * \\
(-2.088)\end{array}$ & & \\
\hline Private external debt stocks & & $\begin{array}{l}-0.0264 \\
(-1.118)\end{array}$ & & & $\begin{array}{l}-0.0172 \\
(-0.561)\end{array}$ & \\
\hline Public external debt stocks & & & $\begin{array}{l}-0.0686 \\
(-1.175)\end{array}$ & & & $\begin{array}{l}-0.127^{*} \\
(-1.703)\end{array}$ \\
\hline \# of countries & 430 & 331 & 426 & 430 & 331 & 426 \\
\hline \# of instruments & 89 & 75 & 89 & 89 & 75 & 89 \\
\hline AR (2) test & 74 & 74 & 74 & 74 & 74 & 74 \\
\hline Hansen test & 0.260 & 0.398 & 0.285 & 0.223 & 0.200 & 0.200 \\
\hline Initial GDP per capita & 0.279 & 0.620 & 0.349 & 0.334 & 0.404 & 0.264 \\
\hline
\end{tabular}

Note: See Notes to Table 1.

Table 2. External Debt and Disaggregated Investment

\section{Conclusion}

In this study, we investigate the effect of total, public and private external debt stocks on total, public, and private investment by using data for a large group of developing countries with the system GMM. We find that external debt exerts a significant and negative effect on investment levels. Our results also clearly indicate that the effects of external debt on government and private investment levels are substantially different. Moreover, we do not find any significant effect of external debt on public investment. We then conclude that total and public but not private external debt have negative effects on private investment, strongly confirming the predictions of debt overhang hypothesis. We find this result rather intuitive since what matters for private investment decisions is public but not private external debt stock.

\section{References}

- $\quad$ Baum, C. F., Schaffer, M.E. and Stillman, S (2003). "Instrumental Variables and GMM: Estimation and Testing", Stata Journal 3, 1-31.

- Clements, B., Bhattacharya, R. and Nguyen, T. Q. (2003). "External Debt, Public Investment, and Growth in Low-Income Countries", IMF Working Paper Series, WP/03/249.

- Cohen, D. (1993). "Low Investment and Large LDC Debt in the 1980s," American Economic Review, 83(3), 437-449. 
- Cordella, T., Ricci, L.A. and Ruiz-Arranz, M. (2005). "Debt Overhang or Debt Irrelevance? Revisiting the Debt-Growth Link," IMF Working Paper Series, WP/05/223.

- Daud, S. N.M and Podivinsky, J.M. (2012). "Revisiting the Role of External Debt in Economic Growth of Developing Countries", Journal of Business Economics and Management, 13(5), 968-993.

- Deshpande, A. (1997). "The debt overhang and the disincentive to invest", Journal of Development Economics, 52, 169-187.

- $\quad$ Eichengreen, B., Hausmann, R. and Panizza, U. (2007). "Currency Mismatches, Debt Intolerance, and the Original Sin: Why They Are Not the Same and Why It Matters”, ed. S. Edwards, in Capital Controls and Capital Flows in Emerging Economies: Policies, Practices and Consequences, University of Chicago Press, 121-164.

- $\quad$ Feenstra, R C., Inklaar, R. and Timmer, M.P. (2015). "The Next Generation of the Penn World Table" American Economic Review, 105(10), 3150-3182.

- Fosu, A. K. (1996). "The impact of external debt on economic growth: In Sub-Saharan Africa", Journal of Economic Development, 21(1), 93-118.

- Fosu, A. K. (1999). "The External Debt Burden and Economic Growth in the 1980s: Evidence from subSaharan Africa", Canadian Journal of Development Studies, 20(2), 307-318.

- International Monetary Fund (2017). Investment and Capital Stock database.

- Krugman, P. (1988). Financing vs. Forgiving a debt overhang”, NBER Working Paper Series 2486.

- Lee, J-W. and Lee, H. (2016). "Human Capital in the Long Run," Journal of Development Economics, 122, 147-169.

- Mahdavi, S. (2004). "Shifts in the Composition of Government Spending in Response to External Debt Burden", World Development, 32(7), 1139-1157.

- Marshall, M. G. and Jaggers, K. (2005). Political Regime Characteristics and Transitions, 1800-2003. Polity IV Project. Data from http://www.cidcm.umd.edu/inscr/polity/polreg.htm.

- Reinhart, C.M., Rogoff, K.S. and Savastano, M.A. (2003). "Debt Intolerance”, NBER Working Paper Series No. 9908.

- Pattillo, C., Poirson, H. and Ricci, L. (2004) "What Are the Channels Through Which External Debt Affects Growth?” IMF Working Paper Series WP/04/15.

- Sachs, J. D. (1989). “Conditionality, Debt Relief, and the Developing Country Debt Crisis,” Ed. J. D. Sachs in Developing Country Debt and Economic Performance, 255-296. University of Chicago Press.

- Schclarek, A. (2004). Debt and Economic Growth in Developing and Industrial Countries. Unpublished manuscript.

- $\quad$ Sen, S., Kasibhatla, K.M. and Stewart, D.B. (2007). "Debt overhang and economic growth-the Asian and the Latin American experiences", Economic Systems 31, 3-11.

- $\quad$ World Bank (2017). World Development Indicators and International Debt Statistics database. 